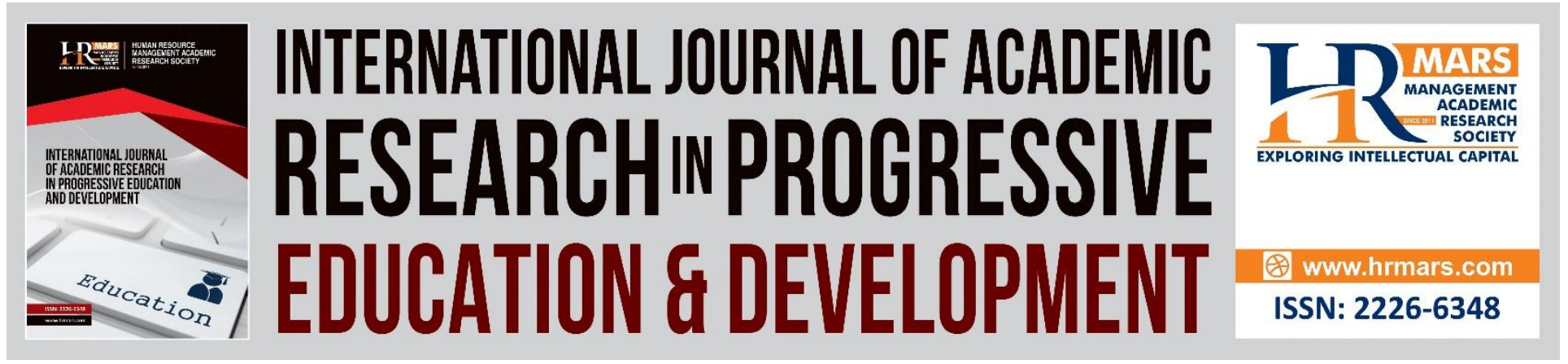

\title{
Theory and Model's: Development of Soft Skill Rubric for The Co-Curricular Subject Among's Matriculation Program Student of the Ministry of Education Malaysia
}

\author{
Aris Hanafi Abu Jalil, Gunathevan Elumalai, Mohd Izwan Shahril
}

To Link this Article: http://dx.doi.org/10.6007/IJARPED/v10-i2/9720

DOI:10.6007/IJARPED/v10-i2/9720

Received: 04 February 2021, Revised: 01 March 2021, Accepted: 27 March 2021

Published Online: 21 April 2021

In-Text Citation: (Jalil et al., 2021)

To Cite this Article: Jalil, A. H. A., Elumalai, G., \& Shahril, M. I. (2021). Theory and Model's: Development of Soft Skill Rubric for The Co-Curricular Subject Among's Matriculation Program Student of the Ministry of Education Malaysia. International Journal of Academic Research in Progressive Education and Development, 10(2), 13-23.

\section{Copyright: (C) 2021 The Author(s)}

Published by Human Resource Management Academic Research Society (www.hrmars.com)

This article is published under the Creative Commons Attribution (CC BY 4.0) license. Anyone may reproduce, distribute, translate and create derivative works of this article (for both commercial and non-commercial purposes), subject to full attribution to the original publication and authors. The full terms of this license may be seen at: http://creativecommons.org/licences/by/4.0/legalcode

\section{Vol. 10 (2) 2021, Pg. 13 - 23}




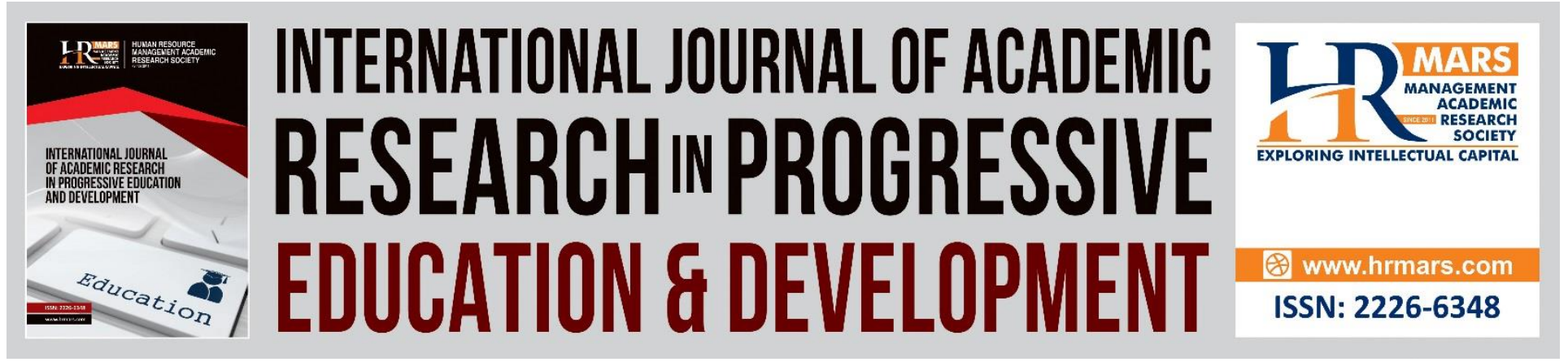

\title{
Theory and Model's: Development of Soft Skill Rubric for The Co-Curricular Subject Among's Matriculation Program Student of the Ministry of Education Malaysia
}

\author{
Aris Hanafi Abu Jalil, Gunathevan Elumalai, Mohd Izwan Shahril \\ Faculty of Sports Science and Coaching, Sultan Idris Education University 35900 Tanjong Malim, \\ Perak Darul Ridzuan, Malaysia
}

\begin{abstract}
The assessment of the Co-curricular subjects in the Matriculation Program now needs to be more effective and clearer in order for Co-curricular Lecturer evaluate students more effectively and systematically against the established soft skills of Lifelong Learning and Teamwork through the Affective domain .The Co-curricular Coordinator needs specific guidance and details for evaluate students throughout the activities and programs they run. In addition, the Lecturers of the Cocurricular are less clear on the level of assessment that should be given when assessing students. Therefore, a standardized assessment section is essential to enable the Co-curricular Lecturers to assess students more clearly and effectively. This study aims to develop a Soft Skills Rubber for Student Co-curicular Matriculation Program. The process of building the Co-curicularFramework is based on the ADDIE Model and the Morrow Model. In addition, the theories related to assessment include the Krathwol Theory of Affective Domain, John Biggs's Theory of Constitutionality, Patrick O'Brien's Theory of Soft Skill (Winning Character), Guidelines to Good Practices: Assessment of Students, GGP: US, ICGPA Rubric: Learning Outcomes Assessment Guide and Curriculum Specification Curriculum Matriculation Program for the element of reasoning. Discussions focus on Teamwork Skills and Lifelong Learning through affective domains. The design of this study is a combination of descriptive and experimental - the one-shot case study. As a result of this study the researcher was able to produce a Soft Skills Rubber for Student Co-curicular Matriculation Program, Ministry of Education Malaysia.
\end{abstract}

Keywords: Co-curricular, Curriculum, Soft Skills Section, Descriptive Study and Pre-Experiment

\section{Introduction}

In the current era of globalization, Malaysia needs a process of structural transformation in various aspects, especially in education field to move towards developed countries. The goal towards the 
INTERNATIONAL JOURNAL OF ACADEMIC RESEARCH IN PROGRESSIVE EDUCATION AND

DEVELOPMENT

Vol. 10, No. 2, 2021, E-ISSN: 2226-6348 @ 2021 HRMARS

formation of developed countries by 2020 and Shared Prosperity Vision 2030 is a mission and vision of the state to mobilize people in the country to be more competitive.

The Formation of Countries would be achieved if the people are always able to compete in skills and high personal qualities comparable to other developed countries.

However, it should be done through a phase of a comprehensive education through training (Nordin, Hamid, \& Jabor, 2005).

In the quest towards developed countries, various aspects need to be considered so that the future generation of the country, especially among students in schools and universities have high selfesteem through a balance of knowledge and morals in the pursuit of challenging employment opportunities.

In addition, students at the level of higher education institutions need to master two important aspects equally in academic and soft skills, this is because both of these skills can produce graduates with high quality human capital to drive the country to a higher level.

There is a major factor experienced by graduates in Malaysia which causes them to remain unemployed due to their weaknesses in the areas of soft skills such as leadership skills, communication skills, teamwork and responsibility as well as critical thinking and problem solving skills (Ibrahim et al.,2019)

Thus, academic and personal balance need to be considered due to the changing scenario of today's education and the economy that require students to prepare themselves for the challenges of the future leaders of the future.

In this regard, Matriculation Program under the Ministry of Education did not miss to jointly drive the students towards a holistic and balanced manner in line with the needs of the current university.

The Matriculation Program of Ministry of Education is the concept of preparatory program for Malaysia Certificate of Education students to qualify for their degree courses in Science, Technology and Professional Literature at public and private universities.

In this regard, the co-curricular for this program has emphasized the balance of academic, curriculum and personal aspects as well as in line with the Ministry of Education's effortsin developing students with a holistic characteristics outlined in the Malaysian Education Development Plan (MEB) 2013- 2025

Implementing aspiration values within the PPPM is designed to enhance students' knowledge and skills in preparation for the 21st century's challenges and needs. 


\section{INTERNATIONAL JOURNAL OF ACADEMIC RESEARCH IN PROGRESSIVE EDUCATION AND}

DEVELOPMENT

Vol. 10, No. 2, 2021, E-ISSN: 2226-6348 @ 2021 HRMARS

\section{Theoretical Skills}

Soft Skills Subject Curriculum for Students Matriculation Program, Malaysia Education values through two aspects, namely soft skills Lifelong Learning and Teamwork through affective domain. According to Figure 1.1, shows construction Rubric Soft Skills Curriculum for the subject based on the ADDIE Model (Rosset, 1987) and Model Morrow, et al. (Morrow et al, 2005).In addition, other theories and guidelines have also been cited and supported such as Bloom's Taxonomy Theory (Krathwohl et al, 1964) of affective domains, Constructive Alignment (Biggs, J.B., 2003), Soft Skills (O'Brien, 2010) These theories are also supported through guidelines such as Curriculum Specification (WK, 002), Malaysian Education Development Plan 2013-2025 (Preschool through Secondary), Malaysian education development plan 2015-2025 (Higher Education Malaysia), Ministry of Higher Education Malaysia (2016 ). Integrated Curriculum: Learning Outcomes Assessment Guide (ICGPA Rubric: Learning Outcomes Assessment Guide) and Good Practice: Student Assessment (Guidelines to Good Practices: Assessment of Students) to build a Curriculum Soft Skills Rubber for Student Matriculation.

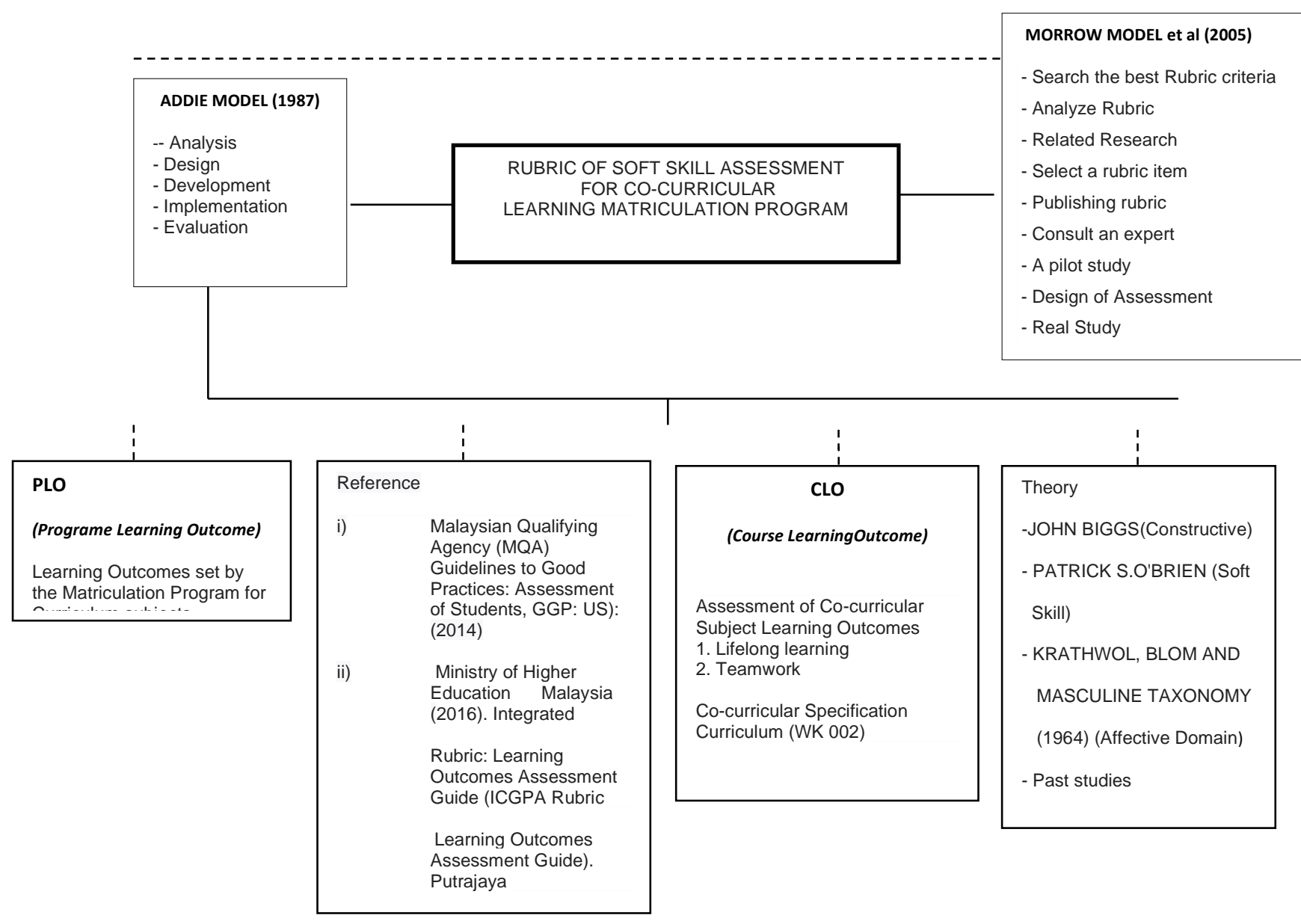

Figure 1.1. Theoretical framework of Rubric Co-curricular Subject Matriculation Programe The Ministry of Education Malaysia 
The ADDIE model is a design model founded by Rosset (1987). This model plays an important role in providing guidance on software development as well as teaching and learning materials based on need. The purpose of this model is to create an assessment of teaching and learning so that the delivery of a lesson will be more effective and efficient. This ADDIE model covers several phases of evaluation construction. There are five phases involved in this model.

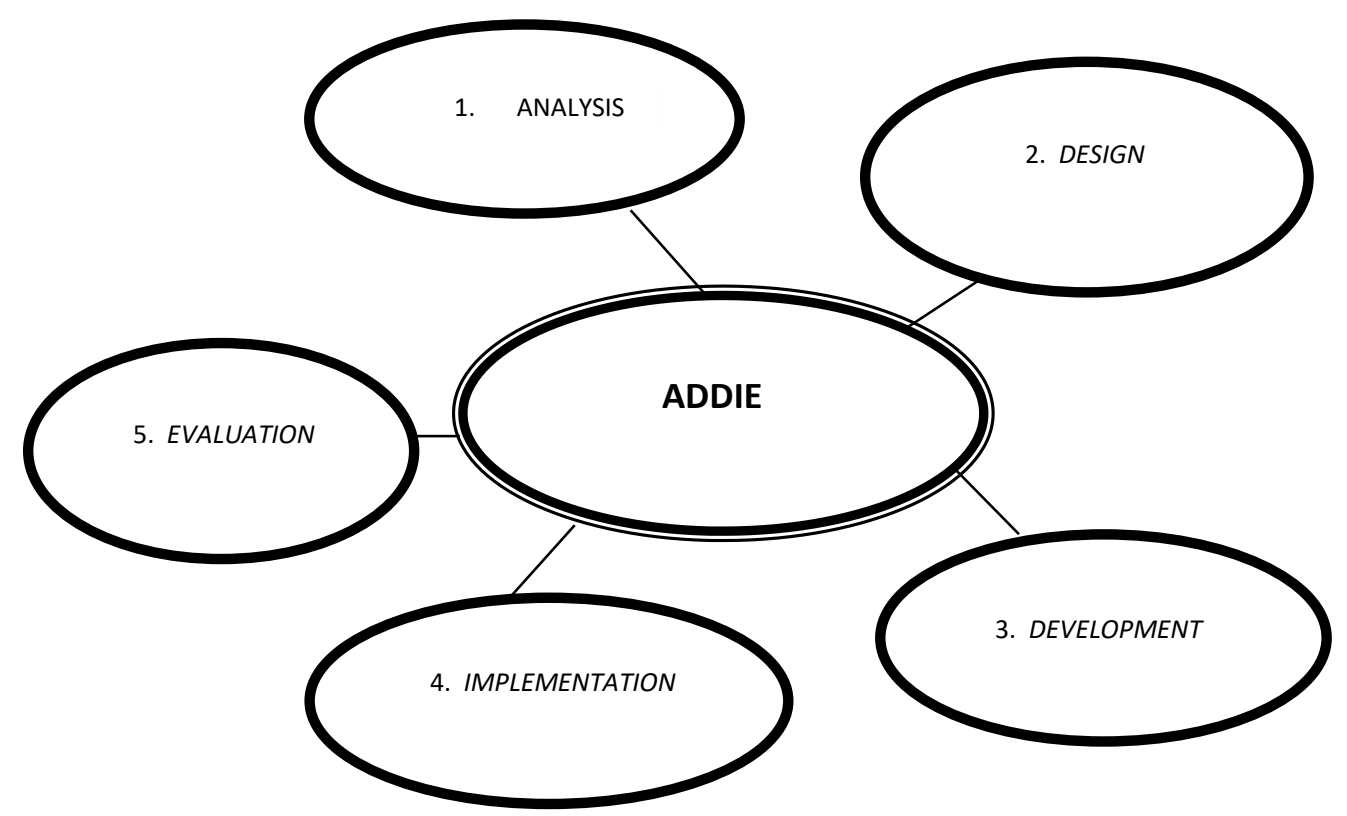

Figure 1.2. ADDIE Model (Rossett , 1987)

\section{Analysis}

The analysis phase is the process to clarify the problem, identify the source of the problem and determine the solution in this study. This phase of the analysis requires the researcher to perform the requirement, job analysis and task analysis. The output of this phase includes the teaching goals and the learning outcomes set. The outputs in this phase will be an input into the design phase later. This phase will explain the main factors of this study.

\section{Design}

This phase is formed and lay out the objectives and content of the study is based on theories andbased on the theories and models that fit the study. The design is also anoutline on how to achieve the aim of the study or output through the study framework. In addition, past studies have also been used to produce effective content. The output in the design phase will be the input to the next phase of development.

\section{Development}

This phase is built based on the analysis and design phase. The purpose of this phase is to produce a Soft Skills section for the Matriculation Program Co-curricular Subject, Ministry of Education 
INTERNATIONAL JOURNAL OF ACADEMIC RESEARCH IN PROGRESSIVE EDUCATION AND

DEVELOPMENT

Vol. 10, No. 2, 2021, E-ISSN: $2226-6348$ @ 2021 HRMARS

Malaysia. During this phase will be to develop measures that will be used in the assessment of teaching and other required documents. This phase involves the evaluation process of lecturers towards students and the production of learning materials and the main purpose of this phase is to ensure the content of the syllabus and assessment meet the requirements and specific learning outcomes for Curriculum subjects.

\section{Implementation}

This phase explains the process of assessing the student's Soft Skills assessment conducted by the Matriculation Program Lecturer through a briefing to all the Curriculum Lecturers. In addition, this phase also helps lecturers understand the rubric and develop assessment during the teaching and learning sessions. This will help the lecturer reflect on the teaching and learning that takes place. This phase can support to further the next phase which is the evaluation phase to determine the extent of this section meet the requirements of the program

\section{Evolution}

This phase is the final phase after the analysis, design, development and implementation phase. This final phase is a formative evaluation phase to ensure that the research is met to the best of our ability. The feedback obtained through the assessment will be used to improve the planning and content of the soft skills section.

\section{Construction of Instrument Rubric of Soft Skill}

Figure 1.3, show the Construction of Instrument Rubric of Soft skill refer to Morrow's Model (Morrow et al., 2005), researchers use Rubric's construction guide in the process of building Rubric items at the development stage. 
INTERNATIONAL JOURNAL OF ACADEMIC RESEARCH IN PROGRESSIVE EDUCATION AND DEVELOPMENT

Vol. 10, No. 2, 2021, E-ISSN: $2226-6348$ @ 2021 HRMARS

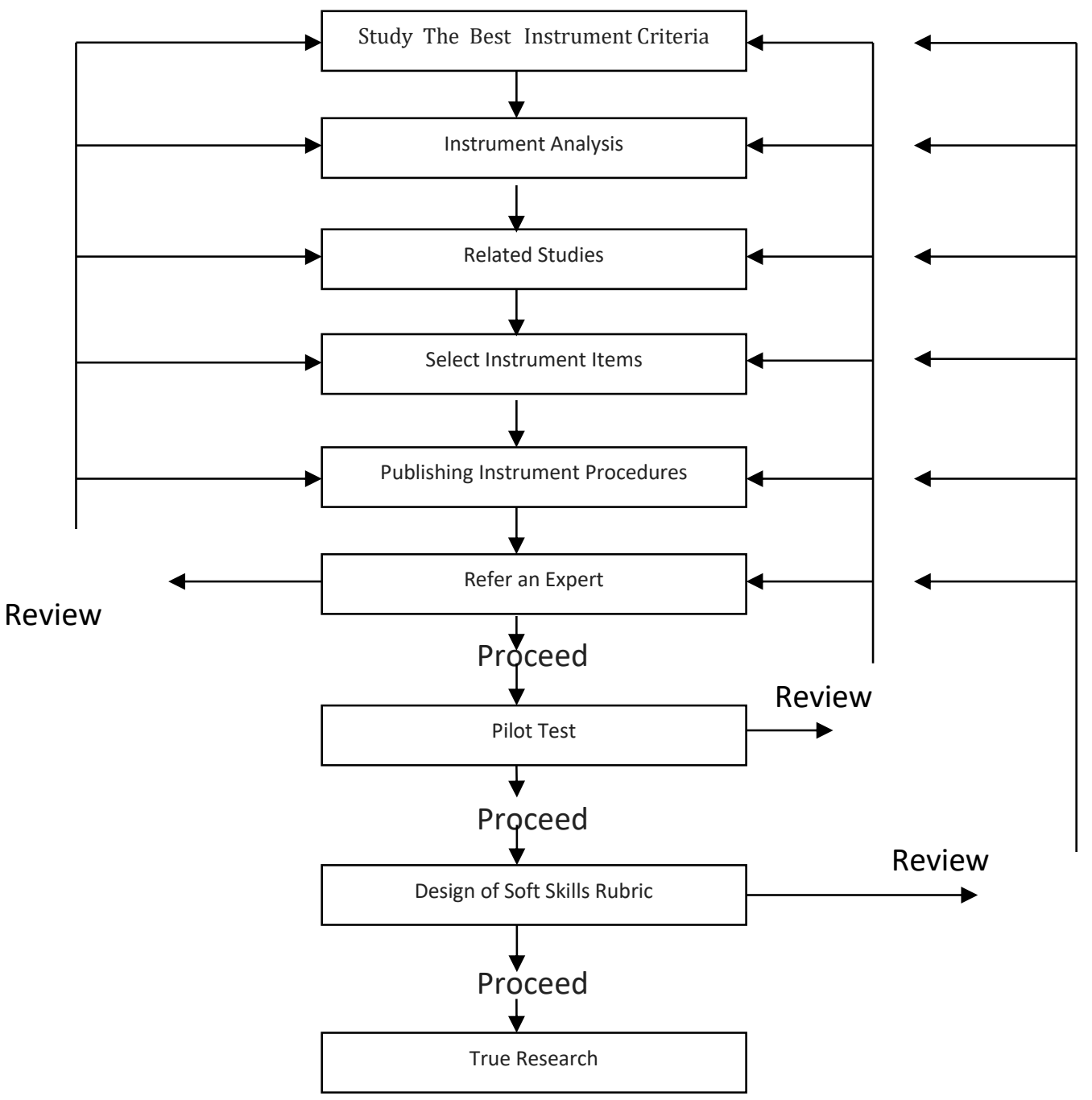

Figure 1.3. Construction of Instrument Soft Skill Rubric for Co-Curricular Matriculation Programe

\section{Program Learning Outcome (PLO) And Course Learning Outcome (CLO)}

Evaluation is an important part of the learning and teaching process, assessment method or learning outcomes indicators and should be developed in line with programe learning outcome (PLO) and course learning outcome (CLO). Therefore, in directly it encourages students to adopt a learning approach that will result in course learning outcome achievement and in support of programme learning outcome achievement as shown in figure 1.4. This section also complies with the programe learning outcome and course learning outcome guidelines set for the Curriculum curriculum in the Matriculation Programe. 


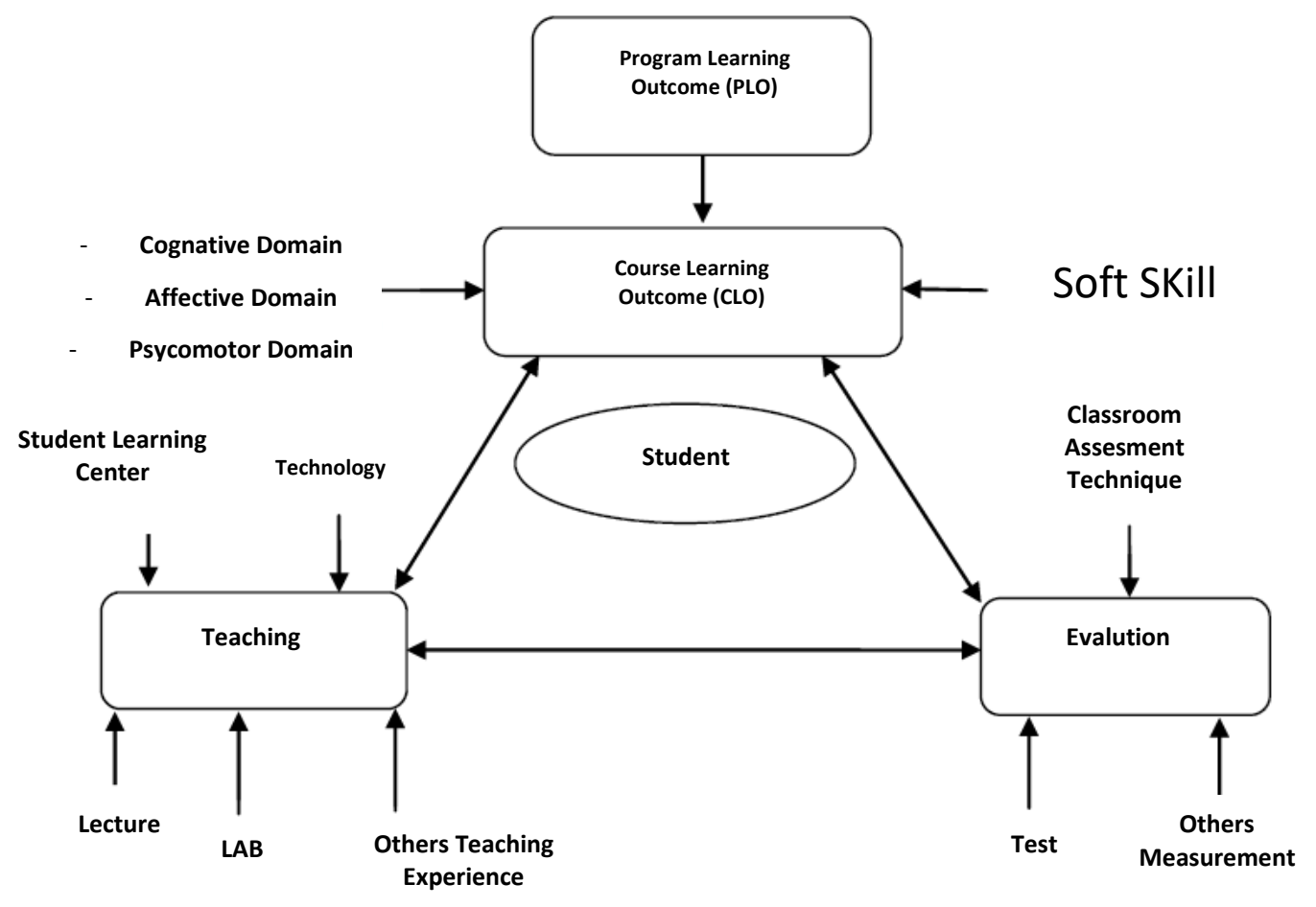

Figure 1.4. Relationship between Curriculum Design, Delivery ana Assessment

(Adapted by the Malaysian Framework Agency (2013) from Felder, R. M. \& Brent, R. (2003). Designing and Teaching Courses to Satisfy the ABET Engineering Criteria. Journal of Engineering Education, 92 (1), 7 - 25.)

\section{Soft Skill}

According to Elfindri (2011), Soft skills are defined as behaviors that include life skills and skills, be it self, group, or community, and god. Having Soft Skills makes one constantly surrounded by the community. Communication, emotion, language, group, ethical and moral skills are areas of Soft skills.

\section{Teamwork}

In leading of an association and club, cooperation among members is essential to ensure that the activities of the association and club work well. Therefore, teamwork and work spirit will give members and clubs the opportunity to share their ideas and insights. According to Mansor (2008), Teamwork means work done by having the same goal in a group even though individuals in the group have different ways of working to complete a task. This was also supported by Gallie, Zhou, Felstead \& Green (2012) teamwork skills involve the ability to work together with others to achieve the same goal.

\section{Life Long learning}

According to Chen and Liu (2014), the lessons learned earlier are important and should be used for the foreseeable future. Carson (2010), however, thinks that lifelong learning is a never-ending and ever-changing and requires a lot of effort. Bollegala et al. (2011) stated that transfer of learning does not just happen to one learning source but it may be more than one to enhance knowledge. 
INTERNATIONAL JOURNAL OF ACADEMIC RESEARCH IN PROGRESSIVE EDUCATION AND

DEVELOPMENT

Vol. 10, No. 2, 2021, E-ISSN: $2226-6348$ @ 2021 HRMARS

\section{Domain Affective}

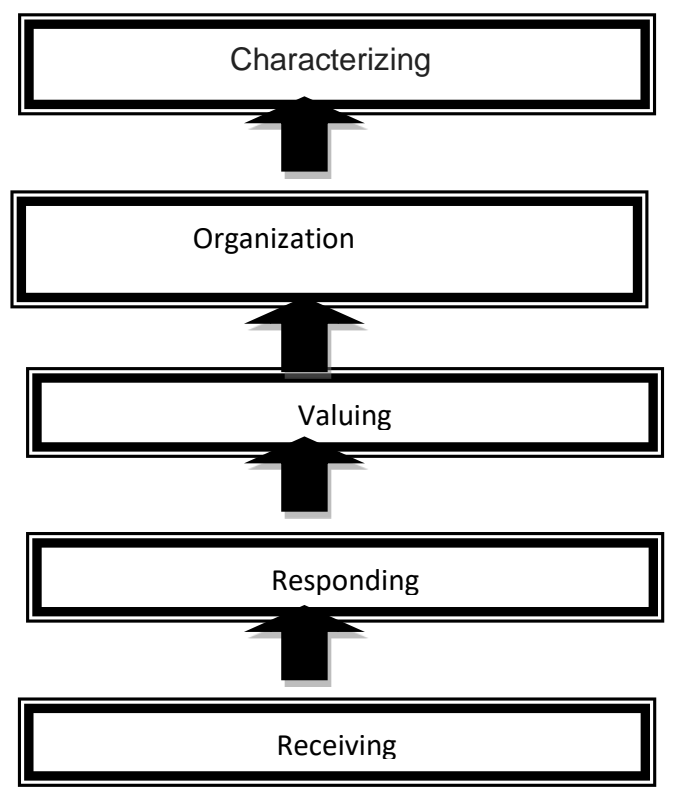

Figure 1.5. Taxanomy Domain Affective (Krathwohl et al., 1964)

Referring to Figure 1.5, The Construction of the Section is based on the Affective domain where the researchers refer to Krathwol et al (1964) Taxanomy as a guide to the Affective domain. There are five levels shared in Krathwol et al (1964), namely Acceptance, Response, Evaluation, Organization and Personality.

\section{Receiving}

Students are comfortable with the situation prevailing in the classroom and the activities carried out and understand the environment and the learning environment. Have the desire and efforts to improve themselves and friends

\section{Responding}

Students are always motivated and active during learning activities. Students are always positive and creative in their actions to achieve the goals of themselves and their peers

\section{Methodology of The Study}

In this study the design of the study used was a combination of descriptive and pre-experimental case study (the one-shot case study). According to Shahril, et al (2015), Salimin, et al (2014) and Sidek and Jamaluddin (2005) Descriptive studies are aimed at explaining the facts and characteristics of a population accurately and systematically. Referring to Shahri (2017), Gay, Mills \& Airaisan (2009) a one-shot case study (one-shot case study) involving a group and exposed to treatment (X) and Testing post $(\mathrm{O})$ in addition to no control over the group 
INTERNATIONAL JOURNAL OF ACADEMIC RESEARCH IN PROGRESSIVE EDUCATION AND DEVELOPMENT

Vol. 10, No. 2, 2021, E-ISSN: $2226-6348$ @ 2021 HRMARS

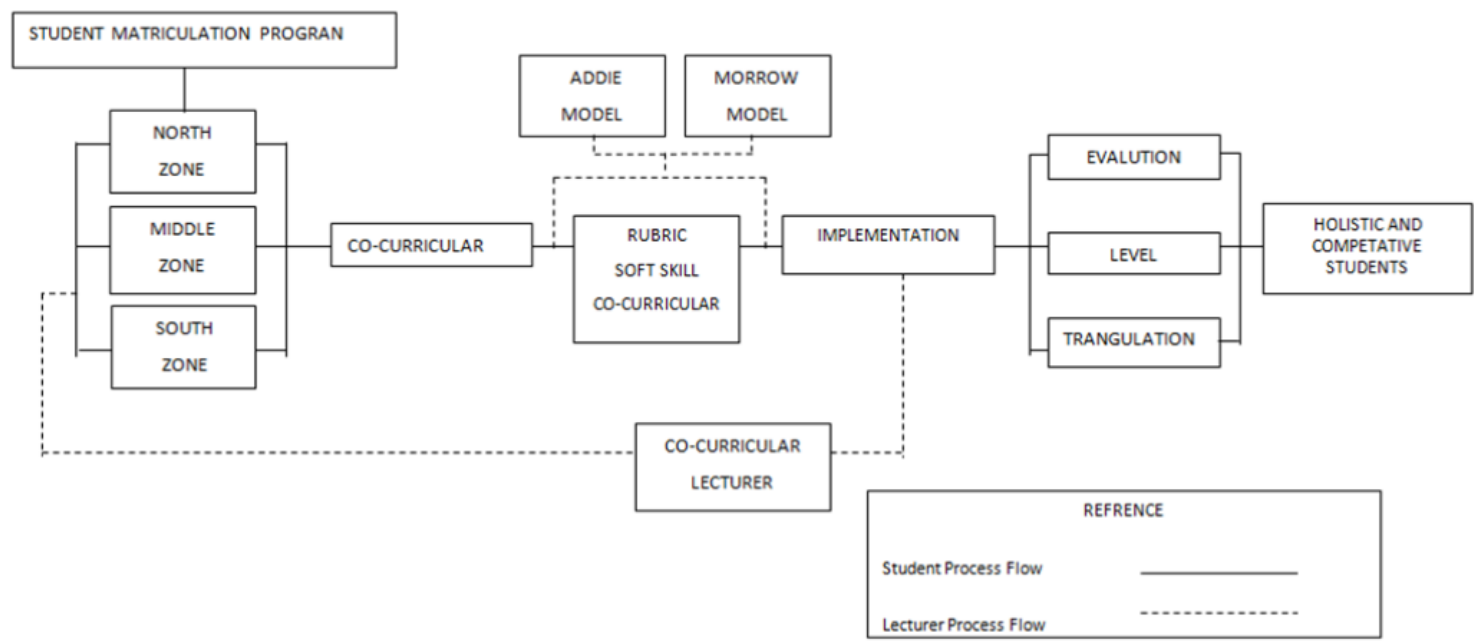

Figure 1.6. Conceptual Framework of Study

\section{Conclusion}

The standard section on assessing the student's Soft Skills level is crucial for developing a holistic student. This assessment section will assess the extent to which students' Life and Work Team Learning skills are maintained throughout the curriculum. In addition, this assessment section will also help lecturers towards a greater goal in developing students' self-esteem in the face of more challenging future challenges.

Overall, the Development of Soft Skills for Curriculum Subject for student Matriculation Program is very important in assessing the potential of students especially in the Matriculation Program with a standardized assessment. The soft skills of matriculated students can be enhanced to meet the holistic human capital requirements in line with the Malaysian Education Development Plan 20152025 (Higher Education Malaysia). Through the assessment and the Modules can also help the University and employers evaluate the potential of graduate students from the Matriculation Program to face more competitive challenges when they are in the University and field of work In addition, this model also can be assist in the development of other rubrics for affective domains in learning other than co-curricular learning and can also be implemented in multiple stages with more detailed studies related to the organization to be studied.

\section{References}

Biggs, J. B. (2003). Teaching for quality learning at university. Buckingham: Open University Press/Society for Research into Higher Education. (Second edition)

Bollegala, Weir, J. D., \& Carroll, J. (2011). Using Multiple Sources to Construct a Sentiment Sensitive Thesaurus for Cross-Domain Sentiment Classification Proceedings of the 49th Annual Meeting of the Association for Computational Linguistics, pages 132-141, Portland, Oregon, June 19-24, 2011

Chen, Z. Y., \& Liu, B. (2014). Topic Modeling using Topics from Many Domains, Lifelong

Elfindri, D. K. K. (2011). Soft Skills untuk Pendidik. Jakarta: Baduose Media 
INTERNATIONAL JOURNAL OF ACADEMIC RESEARCH IN PROGRESSIVE EDUCATION AND

DEVELOPMENT

Vol. 10, No. 2, 2021, E-ISSN: $2226-6348$ @ 2021 HRMARS

Gallie, D., Zhou, Y., Felstead, A., \& Green, F. (2012). Teamwork, Skill Development and Employment and Employee Welfare. British Journal of Industrial Relations, 6(9), 78- 88.

Gay, L. R., Mills, G. E., \& Airasian, P. W. (2009). Educational research: Competencies for analysis and applications (9th edition). Upper Saddle River, New Jersey: Prentice Hall. Human Kinetics.

Krathwohl, D., R., Bloom, B. S., \& Masia, B. B. (1964). Taxanomy Of Educational Objectives The Classification Of Educational Goals, Handbook II: Affective Domain. New York: David Mckay Company . Inc

Learning and Big Data. Department of Computer Science, University of Illinois at Chicago MAR/APR 2010. American College of Healthcare Executive

Ministry of Higher Education of Malaysia. (2014). Pelan pembangunan pendidikan Malaysia 20152025 (Pendidikan Tinggi Malaysia). Putrajaya

Nordin, M. S., Abd Hamid, M. Z., \& Jabor, M. K. (2005). Tahap keyakinan kemahiran generik di kalangan pelajar kolej komuniti. Seminar Pendidikan 2005, ms 1-12. http://web1.fp.utm.my/seminar/5.IsuPendidikan05/Kertaspenuh/Kertas\%208.pdf

O'Brien, P. (2010). Making College Count: A Real World Look at How to Succeed in and After College 2nd Edition. ISBN-13: 978-0615394404

Rossett, A. (1987). Training Need Assessment. Englewood Cliffs: Educational Technology Publications.

Shahril, M. I. (2017) Keberkesanan Instrumen Pentaksiran Pembelajaran (IPP) Berasaskan Teaching Games For Understanding (TGFU) Bagi Permainan Badminton. Doctoral dissertation, Universiti Pendidikan Sultan Idris.

Sharil, M. I., Norkhalid, \& Gunathevan, E. (2015). Validity and Realibility of ISO Test Toward The Performance Assesement of future Physical Education Teachers in Teaching and Learning Proces. Procedia-Social and behavioral Science 00 (2015) 000-000.

Sidek, M. N., \& Jamaluddin, A. (2005), Pembinaan Modul Bagaimana Membina Modul Latihan dan Modul Akademik. Serdang Selangor: Penerbitan UPM 